\title{
Flexible Sovereignties of the Revolutionary State: Soviet Republics Enter World Politics
}

\author{
Sabine Dullin \\ Sciences Po, Paris, France \\ sabine.dullin@sciencespo.fr \\ Etienne Forestier-Peyrat \\ University of Valenciennes, Valenciennes, France; Sciences Po, Paris, France \\ etienne.peyrat@sciencespo.fr
}

\begin{abstract}
When Stalin demanded in 1944 that all Soviet Union republics be admitted to the UN, he revealed a conception of sovereignty that diverged from the usual perception of Soviet diplomacy as exceedingly centralised. Soviet theories and practices of sovereignty consisted indeed in a mix of contradictory elements, illustrating the communist criticism of bourgeois international law, but also a willingness to re-use parts of it and tailor them to new political needs. This article focuses on this elastic approach to sovereignty, its legal expression and diplomatic rationale. Particular attention is paid to the sovereignty of Union republics, central to Soviet legal rhetoric, that led them to be active in the international arena in the 1920s and after 1944, and develop state institutions that would smooth up the transition to independence after 1991.
\end{abstract}

\section{Keywords}

Soviet Union - sovereignty - federalism - subjects of international law paradiplomacy - Ukraine - Communism - law of treaties

"We now suggest to enable Union republics to establish direct diplomatic relations with foreign states and sign treaties with them", Soviet People's Commissar for Foreign Affairs Vjacheslav Molotov solemnly announced at the end of 
January 1944, during a Central Committee plenum of the Party. ${ }^{1}$ This speech introduced a reform that created republic commissariats for Foreign Affairs and Defence, two fields that seemed previously to be the preserve of Soviet federal authorities. There was however, Molotov contended, no discontinuity or contradiction in this measure. Full mobilisation for the war had entailed deeper integration for Soviet nationalities, and these new republic powers (polnomochija) meant a simultaneous strengthening of republic and federal sovereignties. Without entering into theoretical debates, the Commissar for Foreign Affairs reminded the audience that since its first days the communist state had been developing an original practice as far as the place of Soviet republics in international affairs was concerned. ${ }^{2}$ Their becoming subjects of international law with a treaty-making capacity was a development - though a portentous one - of the Soviet approach to sovereignty, unveiling what had been the 'latent sovereignty' of the republics according to a Soviet international law textbook. ${ }^{3}$

The 1944 reform, enforced through constitutional amendments to federal and republic constitutions, may seem at first sight at odds with the perception, dominant since the 1930s, that Soviet statesmen, diplomats and lawyers had a conservative approach to sovereignty, as a 'supreme power, unlimited within the boundaries of the state, and independent in external relations' in the words of academician I.P. Trajnin. ${ }^{4}$ Territorial exclusiveness, state diplomacy, military force, as well as state control over key sectors of foreign relations seemed to outline unbounded and centralised Hobbesian sovereignty, a 'quasi-absolute sovereignty' as Marek St. Korowicz put it in the 1950 os. $^{5}$ Although such an attitude characterised Soviet behaviour in many fields of international relations,

1 Our translation. Speech at the Central Committee Plenum of the VKP(b), 27 January 1944, Russian State Archive of Socio-Political Organisations (RGASPI Moscow), f. 82, op. 2, d. 48, ll. $2-3$.

2 Molotov did not mention, though, that Stalin and himself had been fierce opponents of maintaining Commissariats for Foreign Affairs in the republics in 1923 and had criticised 'national communists' on that matter. See Andrei Vyshinsky, The Law of the Soviet State (New York: The Macmillan Company 1948), 264.

3 S.B. Krylov, 'Sojuznye respubliki - sub”ekty mezhdunarodnogo prava', in V.N. Durdenevskyj/ S.B. Krylov, Mezhdunarodnoe pravo: Uchebnoe posobie (Moscow 1946).

4 I.P. Trajnin, 'K voprosu o suverenitete', Sovetskoe gosudarstvo i pravo 2 (1938), 75-108; see too, Sabine Dullin, 'How to wage warfare without going to war? Stalin's 1939 war in the light of other contemporary aggressions', Cahiers du Monde Russe, $5^{2}$ (2-3) (April-September 2011), 221-243.

5 Chapter 'Soviet Conception of Sovereignty and International Law', in Marek St. Korowicz, Introduction to International Law. Present Conceptions of International Law in Theory and Practice (The Hague: Martinus Nijhoff 1959), 108-156. 
it was counterbalanced by an evolutive and adaptable approach to sovereignty, adjusting it to satisfy political aims, following the Leninist principle that law should be 'flexible.6 Such flexibility in an authoritarian state could be seen in the continuity of the Tsarist 'Eurasian' tradition of 're-making the rules.' ${ }^{7}$ This second trend was marked by a willingness to disseminate sovereignty beyond the precinct of central government, thereby using forms of multilevel diplomacy that ran counter to established practices. ${ }^{8}$

This unconventional approach was emphasised by lawyers and international legal experts during the Cold War, notably Henn-Jüri Uibopuu, who devoted a book to the 'legal personality' of Soviet republics in $1975 .{ }^{9}$ Earlier, American émigré political scientist Vernon Aspaturian had inquired into the role of Union republics in Soviet diplomacy since the interwar period. ${ }^{10}$ Both of them tried to combine legal observations with field work in the USSR and contacted the republic ministries of Foreign Affairs to learn first-hand about their missions and the extent of republic sovereignty within the Soviet federal state. After the demise of the Soviet Union, historians became interested in the way the Soviet regime had paradoxically been a major producer of nations and national patterns for all newly independent states. ${ }^{11}$ There, sovereign attributes of the former Union republics were still studied by local scholars from a national perspective, above all in those independent states that were eager to emphasise the historical continuity of their state formations. ${ }^{12}$ The purpose of this

6 Klaus von Beyme, Der Föderalismus in der Sowjetunion (Heidelberg: Quelle \& Meyer 1964), 18-19; Robert Jones, The Soviet Concept of 'Limited Sovereignty' from Lenin to Gorbachev (New York: Palgrave Macmillan 1990); Wilhelm Goerdt, Die 'allseitige universale Wendigkeit' in der Dialektik V.I. Lenins (Wiesbaden: O. Harrassowitz 1962). Jane Burbank, 'Souveraineté eurasienne: un régime, une proposition, un exemple', Histoire@Politique 27 (September-December 2015) doi: 10.3917/hp.027.0074.

8 Bill Bowring, Law, Rights and Ideology in Russia. Landmarks in the Destiny of a Great Power (Abingdon: Routledge 2013); Brian Hocking, 'Bridging Boundaries: Creating Linkages. Non-Central Governments and Multilayered Policy Environments', WeltTrends 11 (1996), $3^{6-51 .}$

9 Henn-Jüri Uibopuu, Die Völkerrechtssubjektivität der Unionsrepubliken der UdSSR (Vienna: Springer Verlag 1975).

10 Vernon V. Aspaturian, The Union Republics in Soviet Diplomacy. A Study of Soviet Federalism in the Service of Soviet Foreign Policy (Geneva: Droz 1960).

11 Terry Martin, The Affirmative Action Empire. Nations and Nationalism in the Soviet Union, 1923-1939 (Ithaca-London: Cornell University Press 2001); Francine Hirsch, Empire of Nations. Ethnographic Knowledge and the Making of the Soviet Union (Ithaca, NY: Cornell University Press 2005).

12 For the Belarusian case, see Vladimir Snapkovskij, Put' Belarusi v oon 1944-1945 gg. (Minsk: Nauka i Tekhnika 1994). 
article is to reassess the revolutionary part of the Soviet legal strategy' (stratégie juridique) in the international arena by an analysis of both legal conceptions of sovereignty and diplomatic practices including at the level of the republics. ${ }^{13}$ Flexible sovereignty might indeed have been a key factor for understanding the legal and political transition between the USSR and its successor states.

\section{$2 \quad$ An Alternative Community of States}

In his speech, Molotov insisted that the reform was essentially a return to the situation of Soviet republics before the creation of the Soviet Union in 1923. Until that date, each republic enjoyed a diplomacy of its own, maintaining diplomatic relations and signing international agreements: diplomatic relations were particularly intense between the republics themselves, with representatives and consuls accredited to each other. ${ }^{14}$ The advance of the Red Army and the consecutive extension of Soviet power in 1919-1921 had legally resulted not so much in annexation of new territories by the Russian Soviet Federative Socialist Republic (RSFSR), as in the creation of nominally independent republics. Whereas the Bolsheviks criticised the legal norms of bourgeois diplomacy as veils for imperialism, they were nonetheless eager to mimic one of the central dimensions of sovereignty in the Western legal tradition, mutual recognition between sovereigns. ${ }^{15}$ Each new Soviet republic was immediately recognised by other republics as a member in what constituted an alternative community of states. Simultaneously, Bolshevik diplomats were keen on obtaining recognition from neighbouring countries, especially those engaged in fights for national independence and against the Entente, as in Turkey where nationalist forces opposed the Sèvres Treaty (August 1920) and sought, too, allies against the European powers. ${ }^{16}$ At the Genoa Conference, the RSFSR was mandated by all Soviet republics as their representative, thus purporting to

\footnotetext{
13 Guy de Lacharrière, La politique juridique extérieure (Paris: Economica 1983), 7-8.

14 Speech at the Central Committee Plenum of the VKP(b), 27 January 1944, RGASPI, f. 82, op. 2, d. 48, 11. 9-11.

15 Janice E. Thomson, 'State Sovereignty in International Relations: Bridging the Gap Between Theory and Empirical Research', International Studies Quarterly 39 (2) (June 1995), 213-233.

16 Bülent Gökay, A Clash of Empires: Turkey between Russian Bolshevism and British Imperialism, 1918-1923 (London: I.B. Tauris 1997); Samuel J. Hirst, 'Transnational Anti-Imperialism and the National Forces. Soviet Diplomacy and Turkey, 1920-1923', Comparative Studies of South Asia, Africa and the Middle East 33 (2) (2013), 214-226.
} 
speak for a whole revolutionary community in the quest for international recognition.

This critical replication of international norms of sovereignty and the existence of a community of republics allowed Moscow to reject responsibility for the actions of communist leaders on the periphery and put pressure on foreign partners. Creating peripheral buffer states was a way to dispel fears about Russian expansionism - a revolutionary adventure in Northern Iran in 1920-1921 was thus sub-contracted to Caucasian Bolsheviks ${ }^{17}$ - or to avoid conflicts with foreign powers, a case made by the role of the Far Eastern Republic (1920-1922) organised to negotiate the withdrawal of Japanese forces present in Eastern Siberia at the time. ${ }^{18}$ A perceptive Austrian traveller crossing the Ukraine, Russia and Transcaucasian republics in 1922 noted:

The unclear legal situation [staatsrechtliche Stellung] of Azerbaijan is a source of discomfort for foreign residents here. Complaints against governmental measures are rejected on the basis that only Moscow takes decisions. If, however, you mention Moscow, you receive the answer that Moscow decrees have no validity in Azerbaijan. ${ }^{19}$

The claims to separate sovereignty were often the result of republican officials genuinely clinging onto what they perceived as one of the achievements of the revolution. Thus, after the Peace of Riga was signed in March 1921 between Poland and the three neighbouring Soviet republics, the management of border incidents demonstrated the willingness of Ukrainian officials and diplomats to assert their territorial sovereignty and negotiate directly with Poland, through active and passive legation, joint commissions and direct exchanges between Ukrainian and Polish institutions. ${ }^{20}$

17 M.A. Persits, Persidskij front mirovoj revoljutsii. Dokumenty o sovetskom vtorzhenii v Giljan (1920-1921) (Moscow: Kvadriga 2009), 6o-61.

18 Ivan Sablin, Governing Post-Imperial Siberia and Mongolia, 1911-1924: Buddhism, Socialism in State and Autonomy Building (Abingdon: Routledge 2016), 147-148; M.A. Persits, Dal'nevostochnaja respublika i Kitaj. Rol' DVR v bor'be Sovetskoj vlasti za druzhbu s Kitaem v 1920-1922 gg. (Moscow: Izdatel'stvo Vostochnoj Literatury 1962).

19 Our translation. Colin Ross, Der Weg nach Osten. Reise durch Russland, Ukraine, Transkaukasien, Persien, Buchara und Turkestan (Leipzig: F.A. Brockhaus 1924), 76.

20 Correspondence between the Ukrainian embassy in Warsaw and the Polish ministry of Foreign Affairs, December 1921 to November 1922, Central Archive of Modern Records (AAN, Warsaw), 322/6811, 10-29, 153-156, 202-203; Sabine Dullin, 'The Interface between Neighbors at a Time of State Transition. The Thick Border of the Bolsheviks (1917-1924)', Annales HSS 69 (2) (April-June 2014), 81-112. 
Foreign actors were well aware too they could derive benefits from this state of affairs. Central European countries, first among them Poland, saw the practical implications of the Bolshevik use of flexible sovereignty. This use was, Law Professor W.L. Jaworski said in 1923, part of the 'ineluctable progress of internationalism [which] will necessarily undermine the intangibility of sovereignty'. ${ }^{21}$ Opinions diverged on the reality of republic sovereignty among Polish diplomats. Józef Targowski, head of the Northern department and former ambassador to Tokyo, emphasised in April 1921 the necessity to look upon the Far-Eastern Republic as an 'entirely different state' from a legal and political point of view, although he admitted strong connections existed between Russia and the Republic. The Polish military attaché to Tokyo did not share this position and was adamant that the Far Eastern Republic was but a puppet state for Moscow leaders. ${ }^{22}$ Beyond legal considerations, the Polish ministry of Foreign Affairs remained very sensitive to national issues in all Soviet peripheries and developed a wide consular network in the Ukraine and the Caucasus, in an attempt to play republic sovereignty against Russia. ${ }^{23}$

A practical dividing line appeared between actors that wanted to exploit the existence of several Soviet republics in order to multiply peripheral contacts and those who privileged direct contacts with Moscow Bolsheviks. British administrations thus debated the best strategy to adopt in commercial matters. ${ }^{24}$ The Board of Trade considered only negotiations with Moscow could bring concrete benefits through a comprehensive trade agreement. On the other hand, the Foreign Office pushed for a real strategy toward the republics, as a way to find new access points to the former Tsarist territory. They notably tried to exploit what they saw as Caucasian autonomy and the desire for recognition manifested by Caucasian Bolsheviks. Lancelot Oliphant, on Lord Curzon's behalf, could thus write that: 'It is the policy of His Majesty's Government to support the Caucasian republics in preserving any degree of independence that may remain in them. ${ }^{25} \mathrm{~A}$ similar argument was made by the Turks, who

21 Czasopismo Prawnicze i Ekonomiczne (XXI) (1923), 268-269, quoted by Wiktor Sukiennicki, Ewolucja ustroju Zwiazku Socjalistycznych Republik Radzieckich, Cz. 1 (Vilnius: Instytut Naukowo-Badawczy Europy Wschodniej 1938), 9.

22 Edward Kołodziej (ed.), Daleki Wschód w świetle wewnętrznych biuletynów centrali Msz oraz raportów polskich placówek z lat 1920-1941 (Warsaw: Wydawnictwo Tekst 2014), 49-50.

23 Etienne Forestier-Peyrat, Retrouver le Caucase. Histoire d'une diplomatie frontalière (19051938) (Ph.D. Dissertation, Sciences Po, November 2015), 579-588.

24 Dennis Ogden, 'Britain and Soviet Georgia, 1921-1922', Journal of Contemporary History 23(2) (April 1988), 245-258.

25 Note of Lancelot Oliphant, FO, to the Board of Trade, 28 June 1921, The National Archive (TNA London), FO 371/6272, f. 144. 
demanded during the Moscow negotiations in March 1921 that Soviet diplomats clarified the situation of Caucasian republics as sovereign republics and unsuccessfully tried to sign separate agreements with each of them. ${ }^{26}$

This community of independent states was of course in large part a community of satellites, tightly bound to Moscow through diplomatic but also Party ties. Ukrainian communists ruled the government of independent Soviet Ukraine, but political subordination to Moscow was enforced through the Ukrainian Communist Party, which remained part of the Russian Communist Party despite enjoying significant leeway. ${ }^{27}$ Political, not legal arguments, explained why the Moscow Politburo, not Ukrainian leaders, could thus decide to make appointments de facto if not de jure of sensitive People's Commissariats in the republic. ${ }^{28}$ This parallel chain of command was emblematic of an original practice of power, that rejected in its first years many of the classical instruments of the state. The ambiguous nature of relations between the RSFSR and the republics is illustrated by a decree adopted on 1 June 1919 by the Russian Central Executive Committee upon a proposal made by the Politburo the same day. ${ }^{29}$ On the basis of military needs it emphasised the necessity to create a unified command over the army, the economy, railroads, finances and People's Commissariats for Labour, all institutions directly concerned with the war effort. Although it was an internal act of Russian organs, this decree explicitly referred to a previous decision of the Ukrainian Central Executive Committee dated 18 May 1919, as well as to requests made by Latvia, Lithuania and Belorussia. ${ }^{30}$ The decision was to be implemented through a process of negotiations with representatives of the republic Central Executive Committees, leaving room for adaptations. This approach was typical of the relationship between the RSFSR and the republics during the phase of the Civil War: while key goals were clearly stated and centrally established, concrete enforcement

26 Minutes of the Russo-Turkish Moscow conference, March 1921, RGASPI, f. 298, op. 1, d. 106, l. 1; Vasif Qafarov, Türkiyə-Rusiya münasibətlarinə Azərbaycan məsaləsi (1917-1922) (Baku: Azərnə̧̧r 2011), 402-406.

27 Volodymyr Lozyts'kyj, Politbjuro TsK Kompartiï Ukraïny: istorija, osoby, stosunky 1918-1991 (Kiev: Heneza 2005), 15-17.

28 Protocol of the Russian Politburo, 28 April 1919, RGASPI, f. 17, op. 3, d. 5, l. 1.

29 'Dekret vTsIK ob ob”edinenii Sovetskikh respublik: Rossii, Ukrainy, Latvii, Litvy, Belorussii dlja bor'by s mirovym imperializmom', 1 June 1919, in I.N. Vladimirtsev (ed.), Sovetskoe sodruzhestvo narodov. Sbornik dokumentov 1917-1922 (Moscow: Izdatel'stvo Politicheskoj Literatury 1972), 90.

30 M.I. Kulichenko, Bor'ba kommunisticheskoj partii za reshenie natsional'nogo voprosa $v$ 1918-1920 godakh (Kharkov: Izdatel'stvo Kharkovskogo Universiteta 1963), 115-116. 
relied upon a mix of interstate agreements, Party hierarchies and diplomatic channels, producing the peculiar dynamics of early Soviet diplomacy.

Chicherin, first People's Commissar for Foreign Affairs, soon demanded a legal clarification on the nature of relations between Soviet republics, in order to delineate spheres of competence and simplify the daily life of Soviet citizens and foreigners. He considered that relations between the RSFSR and Ukraine, for instance, should take the form of a 'confederal union' (Staatenbund), not a 'federal state' (Bundestaat). ${ }^{31}$ The process that gave birth in 1922-1923 to the Soviet Union, with a treaty signed by plenipotentiaries from the four founding republics, was emblematic of the mix between confederal and federal influences. Contemporary works such as N.I. Palienko's Confederation, Federation and Soviet Union (1923) were undecided about the situation, Palienko calling it a 'peculiar confederal structure.' ${ }^{32}$ Several decades later, this situation turned into an endless source of dispute between Soviet law historians..$^{33}$ The debate, however, was not merely theoretical, as demonstrated years later when separatist forces questioned the legal nature of the 1922 Union treaty as part of their effort to obtain full independence for the republics. ${ }^{34}$

\section{The Roots of People's Sovereignty}

While early Soviet republics copied some of the norms of mutual recognition among sovereign states, their sovereignty was also deeply rooted in the communist approach, best illustrated in Evgueny Korovin's best-known work published during the foundation years of the Soviet Union, International Law of the Transitional Period..$^{35}$ In this work, communist sovereignty was construed as diverging widely from bourgeois theories which claimed exclusive rights to international legal personality for sovereign states and denied any class nature to sovereignty. Working as a senior official for the Russian Society of the Red Cross from 1918 to 1929, Korovin was directly involved in the Soviet effort

31 Our translation. Memo by Chicherin, 6 December 1920, RGASPI, f. 82, op. 2, d. 8, 1l.30-31.

32 O.I. Chistjakov, Vzaimootnoshenija sovetskikh respublik do obrazovanija sssR (Moscow: Gosizdatel'stvo juridicheskoj literatury 1955), 136-137.

33 V.M. Kuritsyn (ed.), Sovetskaja istoriko-pravovaja nauka. Ocherki stanovlenija i razvitija (Moscow: Nauka 1978), 157-159.

34 P.P. Kremnev, Raspad sssR. Mezhdunarodnye-pravovye problemy (Moscow:Zertsalo 2005).

35 Evgueny A. Korovin, Mezhdunarodnoe pravo perekhodnogo vremeni (Moscow: Gosizdat 1923); Jean-Yves Calvez, Droit international et souveraineté en URss. L'évolution de l'idéologie juridique soviétique depuis la Révolution d'Octobre (Paris: Armand Colin 1953). 
to promote the paradiplomatic activity of non-state organisations involved in international relations that helped survive diplomatic ostracism and nonrecognition by Western countries. ${ }^{36}$ Communist sovereignty relied upon principles mainly elaborated since 1917 . Foremost was a distrust of the Tsarist and bourgeois states, which meant priority was given to people's sovereignty. The definition of the 'people', which had a class and national content, had been a moot point for years between Bolshevik leaders. During the Eighth Party Congress (March 1919), a compromise of a sort had been found, that allowed for adjustable definitions of the people according to the political and socioeconomic maturity of each region. In territories where social differentiation and the working class remained embryonic, the people could be understood in a broad meaning, whereas it was to be restricted to the toiling masses in areas where class struggle was already a reality.

While the republics were a response to the national element of sovereignty, the Soviets naturally translated its class dimension. Since its inception in October 1917, the government of People's Commissars had emphasised its legitimacy based on the Congress of the Soviets. After rejecting the then dominant conception of a classical democracy and although the Bolsheviks allowed elections to the Constituent Assembly to go on at the end of 1917, they remained alien to the idea of universal representation. The Congress headed a full network of workers', peasants' and soldiers' councils that embodied the sovereignty of formerly exploited classes, best illustrated in the dictatorship of the proletariat. All republics emerging from the revolutionary process emphasised this legitimacy by calling themselves 'Soviet'. Whereas ancien régime privileged classes were deprived of rights, forms of affirmative action were created in favour of workers and poor peasants. The conception of citizenship being class-based rather than national, it was logically open to former prisoners of war and foreign proletarians living on Soviet territory. On the other hand, it led to unilateral measures to deprive citizens who had fled the revolution of their nationality. ${ }^{37}$ In 1918, the first Soviet constitutions applied this conception connecting citizenship to social, not strictly national, affiliation. Korovin explained in his book the meaning of Article 20 of the RSFSR Constitution

36 Jean-François Fayet, 'En l'absence de relations diplomatiques et de puissance protectrice: La protection des intérêts soviétiques durant la période dite de transition', Relations internationales 3 (143) (2010), 75-88.

37 Catherine Gousseff, L'exil russe. La fabrique du réfugié apatride (Paris: CNRs Editions 2008). 
(July 1918), that offered 'world citizenship' (mirovoe grazhdantsvo) to Communists of all countries. ${ }^{38}$

Nations were, however, another important source of sovereignty as conceived by the Bolsheviks. From 1903 on, the Russian Workers' Social-Democratic Party had included the right to self-determination in Article 9 of the Party platform. Until 1917, Lenin interpreted it as a right of secession and Stalin himself - whom Lenin then called his 'wonderful Georgian' - had helped him refute popular theories of federalism and autonomy influenced by AustroHungarian Marxists (Otto Bauer, Karl Renner). In Spring 1913, Stalin penned a series of articles devoted to 'Marxism and the National Question' where he developed this criticism at length. ${ }^{39}$ As the 1917 Revolution unfolded, Bolshevik leaders observed the influence of federalist ideas in the peripheries of the former empire. Even in Ukraine, where national forces quickly gained momentum, a federal bond with Russia remained the most popular option. The third Universal promulgated by the Ukrainian Rada on 7 November 1917 stated: 'Without separating ourselves from the Russian Republic and maintaining its unity, we shall stand firmly on our own soil, in order that our strength may aid all of Russia, so that the whole Russian Republic may become a federation of equal and free peoples. ${ }^{40}$ With federalism as the rallying cry for the peripheries of the revolution, the Bolsheviks and Lenin himself moved to adopt a programme which astutely combined federalism and the right of secession.

The right of secession was implemented by the two decrees that followed in October 1917: the Decree on Nationalities enshrined the right of all non-Russian peoples to self-determination, while the Decree on Peace denounced all forms of annexation by force, defined as the incorporation of a nation that had not had the opportunity to vote freely on the forms of its national existence. The right of secession was later integrated into Soviet constitutions and survived all attempts to eliminate it during constitutional revisions of the 1930 s and 1960s-1970s, although constitutional provisions never provided a clear roadmap for its possible implementation. ${ }^{41}$ The reality of this right became the

38 Korovin, Mezhdunarodnoe pravo perekhodnogo vremeni (n. 55) (1923), 31.

39 Joseph Stalin, Marxism and the National Question. Selected Writings and Speeches (New York: International Publishers, 1942); Alfred J. Rieber, 'Stalin as Georgian: The Formative Years', in Sarah Davies/James Harris (eds.), Stalin. A New History (Cambridge: Cambridge University Press 2005), 18-44.

40 Taras Hunczak (ed.), The Ukraine, 1917-1921: A Study in Revolution (Cambridge, MA: Harvard Ukrainian Research Institute 1977), 382-395.

41 A. Shtromas, 'The Legal Position of Nationalities and Their Territorial Units according to the 1977 Constitution of the UssR', The Russian Review 37(3) (July 1978), 269. 
topic of much debate among foreign observers, as a stumbling block for the reality of Soviet commitment to the right of peoples to self-determination. ${ }^{42}$ In order to counterbalance the appeal of secession, federalism was first celebrated in the Declaration of Rights of the Working and Exploited People adopted by the Third Russian Congress of Soviets on 12 (25) January 1918, hailing the RSFSR as a 'a free union of free nations, as a federation of national soviet republics'.43 This text did not fundamentally diverge from that published by the Constituent Assembly that the Bolsheviks had just violently dissolved and which anticipated a Russian Democratic Federal republic made of peoples and regions united by an unbreakable bond, sovereign in the limits set by the federal constitution. ${ }^{44}$

Some Bolsheviks were concerned by this simultaneous process of selfdetermination and sovietisation that led to territorial fragmentation, regarding a socialist future as being founded on unity and centralisation. Lenin had a political interpretation of this fragmentation and declared at the end of 1917:

We are told that Russia will disintegrate and split up into separate republics but we have no reason to fear this. We have nothing to fear, whatever the number of independent republics. The important thing for us is not where the state border runs, but whether or not the working people of all nations remain allied in their struggle against the bourgeoisie, irrespective of nationality ${ }^{45}$

Multiple domestic borders were supposed to be a natural phenomenon for an expanding revolutionary space, called upon to become the 'Socialist United States of Europe'. First launched by Lenin in August 1915, on the eve of the Zimmerwald Conference with the impending demise of Central European autocracies in mind, it was re-used by Trotsky in June 1923 in the middle of a European diplomatic crisis and mass disorders in Germany. ${ }^{46}$ In his view, the European 'madhouse' would be saved by the Bolsheviks thanks to an

42 Edward W. Walker, Dissolution. Sovereignty and the Breakup of the Soviet Union (LanhamBerkeley: Rowman \& Littlefield-Berkeley Public Policy Press 2003), 24-25.

43 Dekrety Sovetskoj Vlasti, T. 125 October 1917 - 16 March 1918 (Moscow: Gosizdatel'stvo Politicheskoj Literatury 1957), 341-343.

44 Burbank, 'Souveraineté eurasienne' 2015 (n. 7).

45 Vladimir I. Lenin, 'Speech at The First All-Russia Congress of the Navy', 22 November [5 December] 1917, Lenin's Collected Works, Vol. 26, (Moscow: Progress Publishers 1972), 341-346.

46 Vladimir I. Lenin, 'O lozunge Soedinennykh Shtatov Evropy' (August 1915), Polnoe sobranie sochinenij, Vol. 26 (Moscow: Gospolitizdat 1967), 354-355. 
economic and constitutional unification process of European socialist republics modelled after the Soviet federation in the making. ${ }^{47}$

In the relationship between peripheral Soviet republics and neighbouring non-socialist countries, class and national emancipation were tightly connected. The 'Piedmont policy' pursued by Soviet leaders aimed at exploiting crossborder national minorities to prepare future expansion. Ukraine and Belarus appealed to co-nationals in Eastern Poland, while some entities were explicitly created with a view to border influence such as Moldavia and Karelia. As early as September 1924, Us diplomat Robert Kelley could give a detailed description of this policy. ${ }^{48}$ Far from the image of overly centralised state and prison of the peoples, the Bolsheviks departed from the unitary political conception that characterised Versailles Europe. They freely used principles of autonomy, federation and confederation whereas many of their contemporaries thought it would mean 'ripping up the state. ${ }^{49}$ In this manner, dealing with the complexities of post-imperial times, they used a wider and more realistic set of instruments than the Allies in 1919, who tried to impose the nation-state on the multi-ethnic and multicultural fabric of Central Europe.

\section{Soviet Republics Go International}

The speech Molotov made on 27 January 1944 was directly connected to a context where divisible sovereignty could once again become an instrument in international diplomacy. As early as 1939-1940, the defence of Ukrainian and Byelorussian sovereignty and national-territorial integrity was conjured up during the process of annexing parts of Eastern Poland. I. Trajnin, the author of the above-mentioned definition of sovereignty, was entrusted with the writing of a text justifying the annexation in the name of people's sovereignty. ${ }^{50}$ The two decrees of the All-Union Supreme Soviet that created republic commissariats for Foreign Affairs and Defence on 1 February 1944 were widely publicised in the republics where constitutional amendments

\footnotetext{
47 Lev Trotsky, 'O svoevremennosti lozunga "Soedinennye Shtaty Evropy”, Pravda, 30 June 1923 .

48 Robert Kelley, 'Soviet policy on the European border', Foreign Affairs, 15 Sept. 1924.

49 Robert Redslob, Le principe des nationalités: les origines, les fondements psychologiques, les forces adverses, les solutions possibles (Paris: Librairie du Recueil Sirey 1930), 190.

$50 \quad$ I.P. Trajnin, Natsional'noe $i$ sotsial'noe osvobozhdenie Zapadnoj Ukrainy i Zapadnoj Belorussii (Moscow: Sotsekgiz 1939).
} 
were adopted in the following months. ${ }^{51}$ The measure was part of the heightened recognition of nationalities and republics that was a product of war mobilisation. Nurtas Undasynov, head of the Kazakh government, thus hailed in April 1944 'the accession of the Kazakh republic to the international arena, the right to establish direct relations with foreign states, to sign agreements with them and exchange representatives' as an 'extraordinary event in the history of the Kazakh people. 52

Beyond internal uses, proclamations of republic sovereignty aimed at weighing on peace negotiations, where Soviet leaders felt isolated in face of Western countries. Late in 1943, they requested that the Soviet republics whose territories had been directly ravaged by war be represented at the United Nations War Crimes Commission. ${ }^{53}$ Although such initiatives pointed to a heightened profile for those Soviet republics which had suffered from war operations on their territories, Americans and Britons were baffled when on 28 August 1944 diplomat Gromyko raised the issue of membership of the UN for all sixteen Soviet republics. This 'bombshell' - as Secretary of State Stettinius later called it - was supposed to consolidate the Soviet position during the Dumbarton Oaks Conference. ${ }^{54}$ Membership of British dominions, and even colonial India, of the League of Nations since 1919 was an important legal argument to counter British and American objections to this demand. A more problematic aspect was the block demand for membership, which camouflaged the problem of the Baltic republics whose annexation in 1940 had not been recognised by Western countries and which were in the process of being re-occupied in August-September 1944.

The Baltic factor obviously played an important role both in Soviet demands and Western refusal, as demonstrated by recent historical scholarship: Westerners were afraid collective admission of Soviet republics to the UN was just a way to bypass their refusal to recognise the forced integration of Baltic republics into the UssR. ${ }^{55}$ Membership for Ukraine and Byelorussia was

$5^{1}$ Samuel Dobrin, 'Soviet Federalism and the Principle of Double Subordination', Transactions of the Grotius Society 30 (1944), 260-283.

$5^{2}$ Our translation. Il'jas Kozybaev, Diplomatija Kazakhstana. Stranitsy istorii (Almaty: Örkeniet 2001), 55 .

53 Yaroslav Bilinsky, The Second Soviet Republic: The Ukraine After World War II (New Brunswick, NJ: Rutgers University Press 1964), 265.

54 Robert C. Hilderbrand, Dumbarton Oaks: The Origins of the United Nations and the Search for Postwar Security (Chapel Hill: The University of North Carolina Press 1990), 95-98.

55 Antonijs Zunda 'Latvijas PSR Ârlietu ministrija un latviešu trimda Rietumvalstīs, 1945. gads - 20. gs. 60 gadi', Latvijas Vēsturnieku komisijas raksti 27 (2011), 196; Ainars Lerhis, 'Latvijas PSR Ārlietu ministrijas darbības pamatvirzieni, 1944-1950', Latvijas Vēsture, 4(68) 
however conceded, and the tactic of mutual recognition was once again used by Soviet leaders in relations between the two republics and the Pro-Soviet Polish National Liberation Committee after September 1944: republic-level bilateral agreements planified population exchanges until the late 1940 s. ${ }^{56}$ More worryingly, republic rights were invoked to justify an aggressive policy against Southern neighbours of the USSR. An ultimatum was launched against Turkey in the name of Georgian and Armenian national sovereignty over border territory, a claim bolstered by analyses produced by the newly established ministry of Foreign Affairs of the two republics. ${ }^{57}$

In the nascent debates of the Cold War, Soviet lawyers argued that Soviet federalism was on a path to ever wider competences for the republic. This claim could be used in a polemical fashion, at a time when North American scholars and legal experts emphasised on the contrary the decline of constituent entities' power in the face of powerful central governments. Particularly popular among lawyers of the USSR Law Institute was the work of British financial and legal expert G.F. Shirras Federal Finance in Peace and War (1944), which heralded the rise of a 'co-operative Federalism replacing the Old Federalism'. ${ }^{58}$ This 'co-operative federalism' was, Iosif D. Levin opined in 1946, a mere byword for the decline of constituent states' rights. ${ }^{59}$ Moreover, us states were deterred by the federal government from developing international relations, in violation of their rights. ${ }^{60}$ Although part of the attack concerned the supposedly diminishing competences of us states, its core was not about content, but about the legal position of these constituent entities. He lambasted bourgeois jurists who refused to see the 'state character' (gosudarstvennyj kharakter) of

(2007), 74-92; Veronika Sajadova, PSRS un Latvija. Starptautisko tiesību pārkāpumi (Riga: Lauku Avīze, 2016).

56 Catherine Gousseff, Echanger les peuples. Le déplacement des minorités aux confins polono-soviétiques (1944-1947) (Paris: Fayard, 2015), 51.

57 Report by Armenian mFA Karapetjan to deputy Soviet MID Kavtaradze 'O byvshikh armjanskikh territorijakh, otoshedshikh k Turtsii i o vozmozhnostjakh vozvrashchenija na rodinu armjan, prozhivaiushchikh za rubezhom', in Arman Kirakosjan (ed.), Armenija i sovetsko-turetskie otnoshenija $v$ diplomaticheskikh dokumentakh $1945^{-1946}$ gg. (Erevan: Natsional'nyj Arkhiv Armenii 2010), 63-76.

58 George Findlay Shirras, Federal Finance in Peace and War. With Special Reference to the United States of America and the British Commonwealth (London: Macmillan \& Co, 1944), 3 .

59 I.D. Levin, 'Desjat" let Stalinskoj Konstitutsii i razvitie sovetskogo federalizma', Sovetskoe Gosudarstvo i Pravo 11-12 (1946), 16.

6 S.Ja. Osherov, Sojuznaja respublika v sotsialisticheskoj federatsii (Moscow: Juridicheskoe Izdatel'stvo Ministerstva Justitsii sssR 1948), 90-91. 
constituent entities. ${ }^{61}$ Among those jurists, Levin singled out Josef Kunz, an Austrian émigré lawyer, a strong opponent to the international personality of such entities.

Levin's argument achieved its criticism of classical sovereignty by introducing new concepts. State 'sovereignty' could be challenged on the one hand by the 'sovereignhood' (suverennost') of peoples - a political concept against colonialism - and on the other hand by 'statehood' (gosudarstvennost'), which indicated the fact of enjoying state attributes such as political-administrative institutions, territory and population. In a sense, statehood was to classical sovereignty in state theory what real rights were to formal rights in the communist criticism of democracy. The criticism of international sovereignty as a mere veil unable to defend weaker states against great-power imperialism was bolstered by a denunciation of the political effects of American aid to Europe through the Marshall Plan. In September 1949, Korovin published 'American Economic Aid and National Sovereignty', a strong indictment of treaties signed between the United States and European countries. ${ }^{62}$ By contrast, Soviet republics supposedly enjoyed both sovereignty and statehood.

In the Soviet conception, statehood could be used as a propaganda tool among Soviet citizens in the republics as well as among émigrés. Unsurprisingly, Western powers were reluctant to give any additional concession on this matter. Legal considerations were foremost in spring 1947, when American diplomats talked their British counterparts out of inquiring about the willingness of Belorussian and Ukrainian authorities to establish direct diplomatic relations. ${ }^{63}$ H.F. Matthews, Director of European Affairs, wrote to Dean Acheson in June 1947:

Separate recognition of the Ukraine would increase the complexity of our relations with the Soviet Union and would give the Soviet Government increased maneuverability in advancing its own special interests in international affairs. ${ }^{64}$

61 Levin, “'Desjat” let Stalinskoj Konstitutsii' 1946 (n. 59), 17.

62 Evgenij Korovin, 'Amerikanskaja ekonomicheskaja pomoshch' i natsional'nyj suverenitet', Sovetskoe Gosudarstvo i Pravo 9 (September 1949), 1-17.

63 For the genesis of this attempt, see the report by British ambassador in Moscow Frank Roberts to the Foreign Office, 11 March 1946, U.E. Snapkoŭski (ed.), Belarus' u palitytsy susednikh i zakhodnikh dzjarzhaŭ (1914-1991 gg.) (Minsk: Junïpak 2015), 158-159.

64 Memo by H.F. Matthews to Dean Acheson, 23 June 1947, in Theofil I. Kis, Nationhood, Statehood and the International Status of the Ukrainian ssR/Ukraine, (Ottawa: University of Ottawa Press 1989), 84 . 
Whereas the British considered the legal battle was already lost, and that at least political and diplomatic advantages should be obtained from the new status of the Ukrainian SSR, the Department of State still thought it possible to prevent Soviet republics, as a members of a federal state, from becoming full subjects of international law. 65

Not all opponents of Soviet power were, however, averse to recognising Soviet Ukraine. A Ukrainian émigré jurist settled in Argentina, Bohdan T. Halajczuk, fathered the most comprehensive attempt to make a case for international recognition of Soviet Ukraine, as a way to accelerate the eventual liberation of the country. In an original work, Ukraine as an Occupied State. The Question of Ukrainian Liberation in an International Law Perspective (1953), he emphasised that Ukraine could not be compared to colonial nations and territories, which did not enjoy statehood. The Ukrainian nation was already a state, admittedly under Soviet tutelage, and the aim was therefore not to create it but to free it. ${ }^{66}$

On the other hand, and what could be a more unexpected development, Soviet ability to combine apparently incompatible forms of sovereignty attracted particular attention in Western countries faced with the challenges of colonial crisis. A 'federal moment' could be observed in the 1940s-1950s that attempted to reshape on more acceptable bases colonial empires while avoiding to resort to the nation-state in non-European contexts. ${ }^{67}$ In France, the constitutional debates of 1946 led to lengthy discussions about federalism as a way to renew the colonial empire and establish a 'French Union' that could reconcile French interests with the requests of colonised populations. ${ }^{68}$ Although the British Commonwealth could serve as an example of successful emancipations of dominions, it was not entirely relevant to the current discussion and some suggested a comparison with the Soviet Union. In August 1946, Edouard Herriot discussed Soviet federalism and called it a 'fédéralisme bien constitué' in contrast to the constitutional bill. ${ }^{69} \mathrm{He}$ was conscious that such a reference could seem polemical, but emphasised the many commonalities of the two

65 E. Dolan, 'The Member-Republics of the U.S.S.R. as Subjects of the Law of Nations', The International and Comparative Law Quarterly 4 (1955), 626-636.

66 Bohdan T. Halajczuk, Natsija ponevolena, ale derzhavna. Ukrä̈n'ka vyzvol'na sprava z mizhnarodno-pravnogo punktu bachennja (Munich: Suchasna Ukraïna 1953), 32-33.

67 Michael Collins, 'Decolonisation and the "Federal Moment", Diplomacy \& Statecraft 24(1) (2013), 21-40.

68 Todd Shepard, 'À l'heure des "grands ensembles" et de la guerre d'Algérie. L'“État-nation" en question', Monde(s). Histoire, espaces, relations 1 (2012), 113-134.

69 Constituent Assembly Debates, 27 August 1946 (second session), Journal Officiel de la République française, No. 83, 28 August 1946, 3334. 
cases: the Soviet Union, as well as the projected French Union, aimed at accommodating nationalities and correcting inequalities while maintaining the supremacy of a core region. This vision enjoyed a great deal of popularity, as demonstrated by the fact that an MP, François Quilici, could similarly praise the Soviet model a year later, during a debate on the statute of Algeria. He emphasised that only strong federal regimes could thwart the separatist trends inherent, according to him, in federalism. ${ }^{70}$

\section{$5 \quad$ Soviet Practices and the Law of Treaties}

Despite this general rejection of Soviet claims about republic sovereignty, these practices exerted a significant but underestimated influence over debates about the subjects of international law. This influence was particularly strong in the process of discussions about the law of treaties in the 196os. As early as 1949, the first session of the International Law Commission included the law of treaties among the topics for codification, appointing in the following years several special rapporteurs. ${ }^{71}$ Ukraine and Byelorussia made full use of their UN membership to accede to several conventions and treaties. Ukraine signed a series of ILO conventions, as well as the Danube Convention (1948), conventions on the law of war and multilateral treaties relating to health, culture and education. ${ }^{72}$ Other Soviet republics, as they did not enjoy UN membership, were more constrained in their policy. Nikita Khrushchev's offensive toward the Third World, in the Middle East and South-East Asia, nonetheless opened a perspective for Central Asian and Caucasian republics in the mid-1950s. Uzbek leader Nuritdin Mukhitdinov was invited to write a blueprint for interactions with the 'East', and the practice of including representatives of the republics in key posts of Soviet diplomacy abroad was reintroduced..$^{73}$ Both the sovereignty and statehood of Soviet republics was emphasised, in an effort to promote the Soviet model of development, but also its influence in the field of legal and

70 National Assembly Debates, 20 August 1947 (third session), Journal Officiel de la République française, No. 99, 21 August 1947, 4484.

71 J.S. Stanford, 'The Vienna Convention on the Law of Treaties', The University of Toronto Law Journal 20(1) (Winter 1970), 18.

72 K.S. Zabihajlo/M.K. Mykhalovs'kyj (eds.), Ukrä̈ns'ka RSR u mizhnarodnykh vidnosynakh (Kiev: Vydavnytstvo Akademiï Nauk Ukraïns'koï RsR 1959); Mykhaïlo Bilousov, Za myr i zahal'nu bezpeku. Zovnishn'opolitychna dijal'nist' Ukrä̈ns'koï RSR v 1959-1963 (Kiev: Vydavnyts'tvo politliteratury Ukraïny 1964).

73 Masha Kirasirova, "Sons of Muslims" in Moscow: Soviet Central Asian Mediators to the Foreign East, 1955-1962', Ab Imperio, 4 (2011), 114-115. 
constitutional arrangements. ${ }^{74}$ Ukraine and Belarus were particularly active in presenting Soviet republics as champions of national self-determination at the 15th session of the UN General Assembly in 1960, that was to adopt a Declaration on the Granting of Independence to Colonial Countries and Peoples. For once they were represented not by their ministries of Foreign Affairs, but by the first secretaries of the republics Communist Parties, Nikolaj Podgornyj and Kirill Mazurov, who travelled to New York with Nikita Khrushchev. ${ }^{75}$

In his first report on the law of treaties in 1962, ILC special rapporteur Humphrey Waldock mentioned Soviet practices as a stimulant for reflection on the legal personality and treaty-making capacity of constituent entities of federal states:

The examples, if not numerous, are important and difficult to overlook in draft articles on the law of treaties; for the Ukraine and Byelorussia are not only Members of the United Nations but have also been admitted as parties to many multilateral treaties in their own right. If both the federal constitution and third States recognize a component State to possess a measure of separate international personality, it seems difficult to deny it any international treaty-making capacity in the present article. ${ }^{76}$

Arguments pro and contra recognition of this treaty-making capacity emerged during domestic and international law debates. A constitutionalist position considered domestic law - i.e. Soviet constitutional amendments of 1944 could be a source of change in international law, whereas internationalists refuted this possibility. ${ }^{77}$ The constitutionalist stance was regularly advocated by Grigory Tunkin at the ILC against reluctant Western colleagues. ${ }^{78}$ Waldock's

74 Alongside a series of international conferences organised in Central Asia, a project was conceived to associate Central Asian republics to the work of the Asian-African Legal Consultative Committee. Letter of the Institute of State and Law of the UssR Academy of Sciences to deputy-Minister of Foreign Affairs V. Semenov, 13 March 1965, Archive of the Russian Academy of Sciences (ARAN, Moscow), f. 1934, op. 7, d. 6o, ll. 65-67.

75 Robert Conquest, Soviet Nationalities Policy in Practice (London-Sydney-Toronto: The Bodley Head 1967), 118.

76 Sir Humphrey Waldock, 'First report on the law of treaties', Yearbook of the International Law Commission, 1962, Vol. II (New York: United Nations Publication 1964), 37.

77 Jean Hostert, 'Droit international et droit interne dans la Convention de Vienne sur le droit des traités du 23 mai 1969', Annuaire français de droit international 15(1) (1969), 104-105.

78 Notably against Alfred Verdross: Bohdan T. Halajczuk, 'The Soviet Ukraine as a Subject of International Law', The Annals of the Ukrainian Academy of Arts and Sciences in the 
remark, however, pointed to the impossibility to ignore the fact that UN membership and signature of several international treaties created an international law basis for the legal personality and treaty-making capacity of Soviet republics.

In the first years of the conference on the law of treaties, Soviet domestic evolutions were tightly interlinked with these international negotiations. Starting from early 1962, Nikita Khrushchev initiated a process of constitutional reform, which notably involved a reconsideration of the Union republics international role. ${ }^{79}$ The Institute of State and Law (ISL) of the USSR Academy of Sciences recommended to suppress from the constitution the article that stipulated that the republics' sovereignty was limited. ${ }^{80}$ Simultaneously, a surge in the diplomatic activity of the republics was noticed. On 1o September 1963, Belorussian Foreign Minister Kiselev suggested that a legal department (dogovorno-pravovoj otdel) be created in his ministry, a request he justified by mentioning the 70 or so covenants, treaties and conventions the BSSR was a party to, and its delegates' activeness in the Sixth Committee (Legal) of the UN General Assembly. ${ }^{81}$ Ukrainian leaders for their own part suggested that the Ukrainian SSR become party to the Moscow nuclear test ban agreement, signed on 5 August 1963 between the UsSR, United Kingdom and Us. The Us State Department reacted quite negatively to this proposal and considered such a ratification superfluous since both Ukraine and Belorussia would be covered by the agreement as 'constituent parts of the USSR'. Besides, the Department claimed that only states maintaining diplomatic relations with the United States were invited to become parties to the agreement. ${ }^{82}$ This position was must plausibly linked with the American stance in the conference on the law of treaties, but was not shared by all Western countries: on 31 March 1963, the Dutch embassy in Moscow contacted the Soviet Ministry of Foreign Affairs, inquiring whether the Ukraine might accede to the Hague Conventions on the

United States, IX 1-2(27-28) (1961), 170-171; Uibopuu, Die Völkerrechtssubjektivität der Unionsrepubliken der UdSSR 1975 (n. 9), 14-15.

79 Grey Hodnett, 'The Debate over Soviet Federalism', Soviet Studies 18 (4) (April 1967), 458-481.

8o Report of the IsL to the constitutional sub-commission on national affairs, 20 June 1964, ARAN, f. 1934, op. 7, d. 7, l. 36 .

81 Report of Kiselev 'Five-year working plan for the ministry (1964-1969)', NARB, f. 4-p, op. 62 , d. 636, ll. 38-46.

82 Transcript of a phone conversation with the us permanent representative to the United Nations, E. Stevenson, 5 October 1963, NARB, f. 4-p, op. 62, d. 637, l. 141. 
laws of war. The answer from the MID's legal department was positive and supported the Ukrainian draft note prepared by Palamarchuk in Kiev. ${ }^{83}$

More specifically, Soviet lawyers argued a clarification was needed on republic rights in matters of signing, ratifying and denouncing international treaties, in order to consolidate their international sovereignty. ${ }^{84}$ This suggestion was directed to disputes in the ILC and later in the Conference on the Law of Treaties (1968-1969). Debates concentrated on article 5, paragraph 2 of the draft convention on the law of treaty. In the final Draft of 1966, article 5 mentioned in paragraph 1 that 'Every State possesses capacity to conclude treaties'. Paragraph 2, however, qualified the statement: 'State members of a federal union may possess a capacity to conclude treaties if such capacity is admitted by the federal constitution and within the limits there laid down. ${ }^{85}$ This formulation became a topic of heated disputes during the Conference of 1968, with a majority of Western countries, notably federal ones, rejecting it. During the discussion of an Austrian amendment to paragraph 2 in April 1968, Byelorussian delegate Kudryavtsev and Ukrainian delegate Lukashuk reminded delegates that 'the member republics [of the UsSR] had not surrendered their sovereignty, which was guaranteed in the constitution of the Union and affirmed in the constitutions of the republics' ${ }^{86}$ On the other hand, us delegate Kearny emphasised that such a paragraph 'would cause difficulties' to other federal states, due to the fact that 'it left too many questions unanswered. ${ }^{87}$ This position was also shared by former British dominions, a fact made clear

83 Ukrainian Central State Archive of State Organizations (TSDAgo, Kiev), f. 1, op. 24, d. 5559, ll.178-184.

84 M.V. Janovskij, 'Suverenitet Uzbekskoj ssR kak ravnopravnogo chlena Sovetskoj Federatsii - sssr - i ee mezhdunarodnaja pravosub"ektnost', O'zbekiston Ijtimoiy Fanlar 1 (1962), 18-19 ; P.E. Nedbajlo, V.A. Vasylenko, 'Mezhdunarodnaja pravosub"eknost' sovetskikh sojuznykh respublik', Sovetskij ezhegodnik mezhdunarodnogo prava (Moscow: Nauka 1965).

85 'Draft Articles on the Law of Treaties with commentaries', Yearbook of the International Law Commission, Vol. II (1966), 191-192; Helmut Steinberger, 'Constitutional Subdivisions of States or Unions and their Capacity to conclude Treaties', Zeitschrift für ausländisches öffentliches Recht und Völkerrecht 27 (1967), 411.

86 Intervention of Lukashuk, 4 April 1968, United Nations Conference on the Law of Treaties. First session Vienna 26 March-24 May 1968 (New York: Un 1969), 66; James P. Nichol, Diplomacy in the Former Soviet Republics (Westport-London: Praeger 1995), 21.

87 Intervention of Kearny, 4 April 1968, United Nations Conference on the Law of Treaties... (1969), 65 . 
during the negotiations by the publication of a Canadian White Paper denying the role of constituent units in foreign affairs. ${ }^{88}$

In the end, article 5 of the Convention signed in May 1969 lost its second paragraph, a setback the Soviets blamed on a plot by bourgeois federations. ${ }^{89}$ Soviet practices nonetheless contributed to giving credence to the idea that non-central state actors, especially component units of federal states, had a legitimacy to be active in the international arena. Generally, the surge of paradiplomacy, i.e. activities pertaining to international relations exerted by noncentral state actors, be they autonomous territories, cities, regions, states, is related to trends in the Western world in the 1970s-1980s. Several explanations have been given for this increasing challenge to central state diplomacy. Some argued that the rise of paradiplomacy could be explained by a state crisis, the emergence of new themes in international relations - notably environmental ones - and the dynamics of globalisation and regional integration that blurred state boundaries and the state's monopoly on foreign relations. ${ }^{90}$ However, as we have seen, Soviet practices, starting from 1917 and into the Cold War, intervened directly in the creation of legal precedents in matters of international recognition of substate actors. The two interpretations are not mutually exclusive, since processes such as regional integration were also felt in the Eastern Bloc, where they too favoured the paradiplomacy of those Soviet republics that border on Central Europe.

\section{6}

\section{Conclusion}

The federal framework, a direct legacy of the Russian revolution, came back to political prominence during Perestroika and turned out to be a key explanatory factor to understand the transition from Soviet Union to independent republics. Sovereignty, due to the term's ambiguity and flexibility, became an effective political weapon for anti-union forces, as Edward W. Walker noted. ${ }^{91}$ The affirmation of republic sovereignty, through budget and legal autonomy,

88 Paul Martin, Fédéralisme et relations internationales (Ottawa: Imprimeur de la Reine 1968).

89 O. Khlestov, 'Pravo mezhdunarodnykh dogovorov', Sovetskoe Gosudarstvo i Pravo 12 (1962), 62-69, quoted by Uibopuu, Die Völkerrechtssubjektivität der Unionsrepubliken der UdSSR 1975 (n. 9), 18-19.

9o Brian Hocking, Localizing Foreign Policy. Non-Central Governments and Multilayered Diplomacy (New York: St. Martin's Press 1993), 1-3.

91 Walker, Dissolution 2003 (n. 42), 6-7. 
became the centre of political action starting from Estonia's proclamation of sovereignty in November 1988 until Russia's declaration in June 1990. Republics striving for sovereignty could rely upon the existing state institutions, which served as the basis for transition between an intra-federal system of interactions to an interstate one. Rather than saying that this was the first genuine expression of republic sovereignty in Soviet history, as Walker and others argued, one could contend that this was the latest avatar of the changing dimensions of Soviet republic sovereignty throughout the century. The growing place of republics in Soviet diplomacy had progressively built a form of international recognition that greatly helped their ascent to the stature of independent countries. Whereas the preceding episodes of this history have been subservient to the centre's interests, this latest one demonstrated that the logic of flexible sovereignty could turn against it. Despite their eventual failure, the Soviets had opened a wide array of political instruments and demonstrated that sovereignty, real or formal, could be challenged and disputed. 